\title{
Local adaptation and transplant dominance in genets of the marine clonal plant Zostera marina
}

\author{
August Hämmerli*, Thorsten B. H. Reusch \\ Max Planck Institute for Limnology, August-Thienemann-Str. 2, 24306 Plön, Germany
}

\begin{abstract}
Worldwide decline of seagrass beds has increased the need for information on potential source populations for recolonization and conservation purposes. The aim of the present study was to test for local adaptation in Zostera marina, the dominant seagrass species of the northern hemisphere. To this end, we performed a reciprocal transplant experiment at the level of the genetic individual (= clone or genet) in 2 Baltic Sea populations for which the clonal structure had been mapped in detail. The treatment effects were tested on aboveground and belowground dry weight of physiologically independent rhizome fragments of replicated genets at the end of the season. We found that genets from both populations produced more biomass in their home population (local adaptation). Genets from 1 population produced more biomass overall (overall dominance) and the range of crosssite performance indicated a high degree of variability among genets within the 2 populations. Our results provide a first test for local adaptation in established seagrass genets and demonstrate home site advantage of clones that are part of a highly connected system of $Z$. marina populations along the Baltic Coast.
\end{abstract}

KEY WORDS: Clonal plants $\cdot$ Local adaptation $\cdot$ Microsatellite $\cdot$ Population differentiation $\cdot$ Transplant experiment $\cdot$ Zostera marina

\section{INTRODUCTION}

Seagrass meadows rank amongst the most productive ecosystems (Costanza et al. 1997), yet they are now threatened by large scale declines which have been taking place over the past decades (Orth \& Moore 1983, Giesen et al. 1990, Short \& WyllieEscheverria 1996). In this context, it has become increasingly important to have information on the suitability of plants from potential donor populations for transplantation and recolonization purposes (Fonseca et al. 1998, Van Katwijk et al. 1998, Williams 2001). One important factor to consider to endear successful recolonization is the ubiquitous presence of local adaptation in naturally occurring plant populations. Plants are sessile with limited seed and pollen dispersal. Hence, local genotypes often reveal re-

*E-mail: haemmerli@mpil-ploen.mpg.de duced fitness in a foreign environment (Antonovics 1971, Antonovics et al. 1971). Alternatively, in clonal plant species, genets may be multipurpose genotypes, which perform well under many habitat conditions (Lynch 1984).

While several studies have looked at factors influencing transplantation and recolonization success in seagrasses (Dennison \& Alberte 1986, Van Lent \& Verschuure 1995, Van Lent et al. 1995, Van Katwijk et al. 1999, Pranovi et al. 2000, Procaccini \& Piazzi 2001), still surprisingly little is known about the degree of local adaptation in marine angiosperms. For example, Van Katwijk et al. (1998) and Van Katwijk \& Hermus (2000) have looked at depth limitation and differential success to an artificially created light gradient in a mesocosm experiment with eelgrass Zostera marina in the Wadden Sea. Worm \& Reusch (2000) found initial shoot density in planted patches to have a positive effect on recolonization in eelgrass in the Baltic Sea. Procaccini \& Piazzi (2001) discovered that growth and rhizome 
branching rate of transplants of Posidonia oceanica was positively associated with the level of genetic diversity in the source population. Most of these studies involved transplantation in 1 direction, prohibiting the detection of local adaptation (Andel 1998). Also, replicated ramets rather than genets were transplanted, which means that the genetic identity of seagrass individuals was unclear.

The aim of the present study was to test for local adaptation in clones of eelgrass Zostera marina, the dominant seagrass species of the northern hemisphere (Den Hartog 1970). To this end, we performed a reciprocal transplant experiment with a total of 20 genotypes from 2 populations on the Baltic Coast, for which the genet structure is mapped in detail. The experiment closely followed a design suggested by Via (1994), which was based on assessing the interaction between 'source site' and 'transplantation site' as a test for local adaptation. Because we were interested in local adaptation at the level of the genetic or evolutionary individual (Janzen 1977), we replicated genets rather than populations. The transplants were physiologically independent rhizome fragments (hereafter 'fragments' from single genets, as they can be found in the field) (Watson \& Casper 1984, Callaghan et al. 1992). This is in contrast to previous studies where transplants were either single shoots or ramets, representing potentially independent units of a clone obtained by breaking the rhizome instead of structures occurring in natural populations.

\section{MATERIALS AND METHODS}

The study system. In the non-tidal Baltic sea, Zostera marina is a long-lived perennial and forms meadows with clones of variable size and age. In established meadows with a closed canopy, seedling recruitment is rare (Robertson \& Mann 1984, Olesen \& Sand-Jensen $1994 \mathrm{a}$, authors' pers. obs.). Thus, open space is mainly colonized through branching and the horizontal growth of rhizomes. The transplant experiment involved 2 sites along the German Baltic Coast separated by ca. $50 \mathrm{~km}$ of coastline. Each site was home to a natural population of $Z$. marina growing in 2.5 to $3.5 \mathrm{~m}$ water depth. The 'Maasholm' population is situated in the estuary at the river Schlei, Schleswig Holstein $\left(54^{\circ} 41^{\prime} \mathrm{N}\right.$, $\left.10^{\circ} 00^{\prime} \mathrm{E}\right)$. The 'Falkenstein' population grows on the west side of the Kieler Förde, Schleswig Holstein $\left(54^{\circ} 24^{\prime} \mathrm{N}, 10^{\circ} 12^{\prime} \mathrm{E}\right)$. Both sites belong to the Kiel Bight water body and therefore have similar salinity and temperature regimes (Reusch 1998). However, the slightly shallower Maasholm population is more prone to disturbance by swan grazing and ice scour than the Falkenstein population (authors' pers. obs.).
Mapping of genets. To obtain plants with known genetic identity, we mapped the clones in large plots at both study sites using genetic markers. During May and June 2000 , two $15 \times 15 \mathrm{~m}$ permanent plots were set-up in shallow water eelgrass beds in both populations using SCUBA. The plots were sampled on a $1 \mathrm{~m}$ regular grid resulting in a total of 1024 samples. Leaf material of plants closest to the grid points was collected and preserved in silica gel for DNA extraction. DNA was extracted with the Qiagen plant DNA extraction kit (Qiagen, Hilden). The DNA extract was processed in a combined PCR amplification using 4 fluorescently labelled polymorphic microsatellite markers (GenBank Accession No. AJ249307, AJ249305, AJ009900 and AJ009898) specifically designed for Zostera marina. The genotyping followed standard protocols (Reusch et al. 2000). Alleles were scored on an ABI 377 automated sequencer, using the software packages GeneScan 3.1 and Genotyper 2.0 (Biosystems Applied 1998). This produced 256 pixel images of the genet composition in the plots. Because the 2 sampled plots within each population were very similar in terms of clonal diversity (number of distinct multilocus genotypes/number of samples) and genet size distribution, they seemed to be representative for the population structure in this area.

In addition to the genetic mapping, $40 \times 40 \mathrm{~cm}$ subquadrates around each grid point were counted for number of shoots, in order to obtain an estimate of shoot density $\mathrm{m}^{-2}$ genet $^{-1}$ for the sampled areas.

Experimental set-up. We tested for local adaptation in genets of Zostera marina with a reciprocal transplant experiment involving replicated genotypes of 2 populations, Falkenstein and Maasholm. In the literature, the term 'ramet' is usually reserved for a potentially independent module in a clonal plant. In this work, we addressed the actual independent rhizome fragment of a genet found in the field (Watson \& Casper 1984, Callaghan et al. 1992), which we call 'fragment'.

From $15 \times 15 \mathrm{~m}$ plots in Falkenstein and Maasholm that had been mapped for clone structure, 10 genets of all genets with $\geq 3 \mathrm{~m}^{2}$ area $(\mathrm{n}=23)$ were randomly selected. Between 17 and 19 Mai 2001, 10 fragments from each of these genets were excavated and stored in tanks filled with ambient seawater for transportation. To obtain effectively independent units rather than potentially independent units, we were careful not to break rhizomes other than within the rotten parts. Each fragment was individually marked with a plastic dented tide (Solana-Arellano et al. 2000) and measured for shoot and rhizome length. Mean rhizome length ( $\mathrm{cm} \pm 1 \mathrm{SEM})$ of fragments for each treatment level was: for Falkenstein, back-transplants $6.57 \pm 0.72$ and transplants $6.03 \pm 0.43$, and for Maasholm, backtransplants $6.62 \pm 0.47$ and transplants $6.67 \pm 0.60$. 
Each fragment had 1 to 3 shoots. Five fragments of each genet were randomly assigned to be planted either back to the source site or to the transplantation site (Fig. 1). All sediment was removed from the rhizome to reduce carry over effects. On 17 and 19 May, fragments were planted in groups of 5 into a randomly chosen genet from where plants (same genet or different genet) had previously been removed. With the aid of a small shovel, rhizomes were lowered into the soft sediment and gently anchored with garden wire pegs.

It would have been ideal to have a mesocosm stage before transplanting the fragments to reduce possible maternal effects (Futuyma 1986). Maternal effects may result from genetic and/or environmentally based differences among maternal phenotypes. In a study on the clonal plant Solidago altissima, Schmid \& Dolt (1994) found that the mean dry mass of seedlings was significantly influenced by both the maternal genotype and the maternal environment. Maternal effects in plants seem to affect mainly early life history stages (seeds, seedlings) (Schmid \& Dolt 1994, Thiede 1998) and appear to be small compared to the effects of genotype and environment (Weiner et al. 1997). Be- cause we were using fragments of well established adult genets and not seeds and seedlings, we assumed such effects to be small for the measured variables.

The experiment lasted $11 \mathrm{wk}$, from the beginning of the growth phase in spring, to seed ripening. Of a total of 200 fragments, 156 fragments (78\%) could be recovered and harvested on 1 and 2 August 2001. The time of harvest was chosen such that flowering shoots had produced seeds, but had not yet started to detach from their rhizome and hence, would have been lost for the aboveground dry weight measurements. To obtain measurements from non-transplanted controls as reference points, a random sample of an additional 20 fragments per source site was harvested 1 wk later. Fragments were transported to the laboratory in tanks filled with ambient seawater, stored in zipped bags at $4^{\circ} \mathrm{C}$ and then measured and prepared for drying.

Fragments were separated in aboveground and belowground biomass by cutting off the shoots above the first root bundle. Epiphytes were removed manually with tissue paper. Aboveground and belowground biomass was determined to the nearest $0.01 \mathrm{~g}$ after drying at $80^{\circ} \mathrm{C}$ to a constant weight.

Statistical analyses. The ANOVA model for genet means $(\mathrm{n}=5$ rhizome fragments) contained 2 treatment factors: (1) source site, fragments were taken from Falkenstein or Maasholm ( $\mathrm{n}=20$ genets); and (2) transplantation site, fragments were transplanted back to source site or to foreign site ( $\mathrm{n}=20$ genets), and 1 random factor (distinct multilocus genotype). Response variables were belowground and aboveground biomass. All analyses were done with the software package GENSTAT (Payne 1997).

Fragments from each of the 10 genotypes at both source sites ( $\mathrm{n}=$ 20 genets, 5 fragments per genet) were randomized within the sites. At the time of planting, rhizome length and shoot height where not significantly different between the treatment levels ( $F$ was always $<2$ and $\mathrm{p}$ always $\gg 0.05$ ).

The reference points (i.e. nontransplanted controls) for shoot and rhizome dry weight were tested against a random subsample of 20 fragments from the backtransplanted fragments in each population using unpaired $t$-tests.

Fig. 1. Experimental set-up to test for local adaptation in genets of the eelgras Zostera marina between $15 \times 15 \mathrm{~m}$ plots in Falkenstein and Maasholm along the Baltic Coast. Transplantations and back-transplantations are indicated with arrows. Each arrow indicates the movement of 5 independent rhizome fragments of which 1 example is shown in the lower right corner of the figure. For reasons of clarity, the transplantation scheme only includes 4 instead of the actual 10 randomly chosen genets in each plot. Please note that allocation of sites (source site or transplantation site) was random and therefore, cases of both transplantation back to the original genet and transplantation into different genets within the same site could occur 


\section{RESULTS}

Mean aboveground dry weight of genets differed significantly between the 2 source populations, Falkenstein and Maashom $\left(F_{1,18}=12.95, \mathrm{p}=0.02\right)$. Most importantly, there was a significant interaction between source site and transplantation site $\left(F_{1,18}=9.69\right.$,
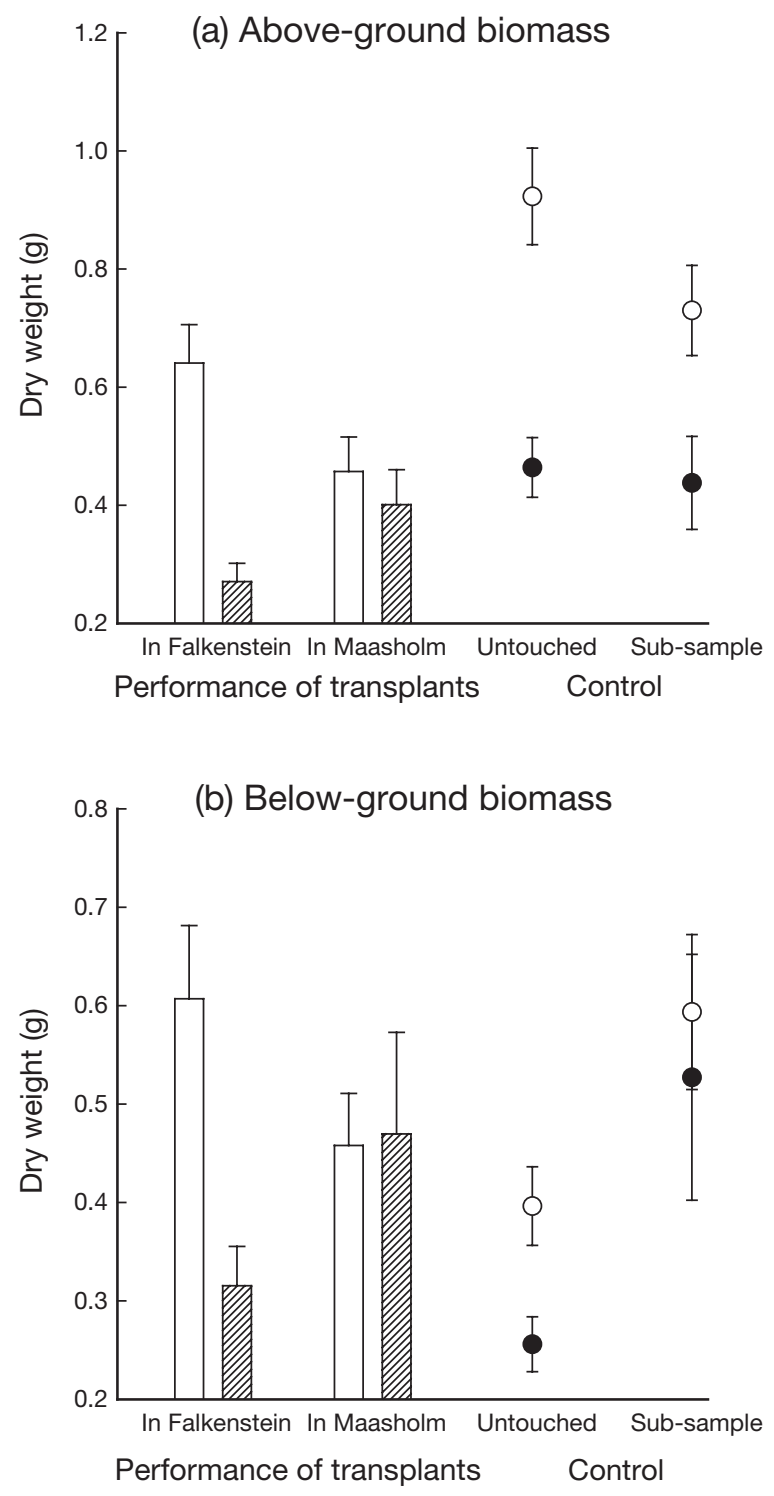

Fig. 2. Zostera marina. Mean dry weight ( $\pm 1 \mathrm{SE}$ ) for (a) aboveground and (b) belowground biomass for genets from Falkenstein (white bars) and Maasholm (hashed bars) reciprocally transplanted between the 2 source sites (mean of 10 genets). Single points on the right side represent random samples of untouched (untransplanted) controls for Falkenstein $(\bigcirc)$ and Maasholm (๑) and random subsamples of backtransplants from Falkenstein $(O)$ and Maasholm $(\bullet)$ against which the untouched controls were tested (means over random samples of 20 independent rhizome fragments) $p=0.006$ ), the test for local adaptation (Fig. 2a). Plants from Falkenstein yielded more aboveground biomass in both populations. Back-transplants in Falkenstein clearly outperformed plants from Maasholm, while transplants from Falkenstein to Maasholm attained similar values as the resident back-transplanted genets in Maasholm. Belowground dry weight measurements did not differ significantly between Falkenstein and Maasholm at the $5 \%$ level $\left(F_{1,18}=3.28, \mathrm{p}=0.087\right)$ but again there was a significant interaction between source site and transplantation site $\left(F_{1,18}=5.31\right.$, $\mathrm{p}=0.033$ ) (Fig. 2b), indicating local adaptation. Backtransplants in Falkenstein outperformed Maasholm plants in terms of rhizome biomass yield, while transplants from Falkenstein to Maasholm attained similar values as the resident back-transplanted genets in Maasholm.

For aboveground biomass, there was no significant difference between untransplanted controls and a random sample of 20 back-transplanted fragments, (Falkenstein: $t_{1,38}=1.72, \mathrm{p}=0.093$; Maasholm: $t_{1,38}=-0.28$, $\mathrm{p}=0.784$ ). However, untransplanted controls showed significantly lower values for rhizome dry weight in both source sites (Falkenstein: $t_{1,38}=2.23, \mathrm{p}=0.031$; Maasholm: $t_{1,38}=2.12, \mathrm{p}=0.041$ ) (Fig. 2).

Of the 156 harvested fragments, 36 bore flowering shoots. This corresponded closely to the natural level of fragments bearing flowering shoots (our unpubl. data). A separate analysis of reproductive biomass only confirmed the results for local adaptation.

Average values per genet and site gave an indication for the range of clonal performance (Via 1994) for the 10 genets from each source population (Fig. 3). One back-transplanted genet from Maasholm was found growing in an open site at the time of harvest. At the time of planting, this patch of meadow had been located close to an erosion front that had moved during the summer and cleared most vegetation by the end of the season, leaving the remaining back-transplants growing in a gap. This value had a strong effect on the overall variance and was considered an outlier (marked with an arrow in Fig. 3). Correlations of performances in both habitats were calculated both with and without this outlier for comparison. The correlation coefficients with outlier were $\mathrm{r}=0.221\left(F_{1,19}=0.944, \mathrm{p}=0.344\right)$ for aboveground and $\mathrm{r}=0.114\left(F_{1,19}=0.235, \mathrm{p}=0.633\right)$ for belowground biomass. Excluding the outlier, we found $\mathrm{r}=0.401\left(F_{1,18}=3.261, \mathrm{p}=0.088\right)$ for aboveground and $\mathrm{r}=0.493\left(F_{1,18}=5.499, \mathrm{p}=0.034\right)$ for belowground biomass. Without the outlier, there was a significant positive correlation for belowground biomass; however, this correlation was weak and not significant for aboveground biomass. Within the sampled plots, we found a higher number of distinct multilocus genotypes, a higher genetic diversity (number of distinct 
genotypes:number of samples) and a higher total number of alleles in Maasholm as compared to Falkenstein. Shoot density $\mathrm{m}^{-2}$ genet $^{-1}$ and mean heterozygosity was not significantly different between the 2 populations $\left(t_{1,222}=1.78, \mathrm{p}=0.077\right)$ and $\left(t_{1,222}=0.60, \mathrm{p}=\right.$ 0.550 ), respectively (Table 1 ).
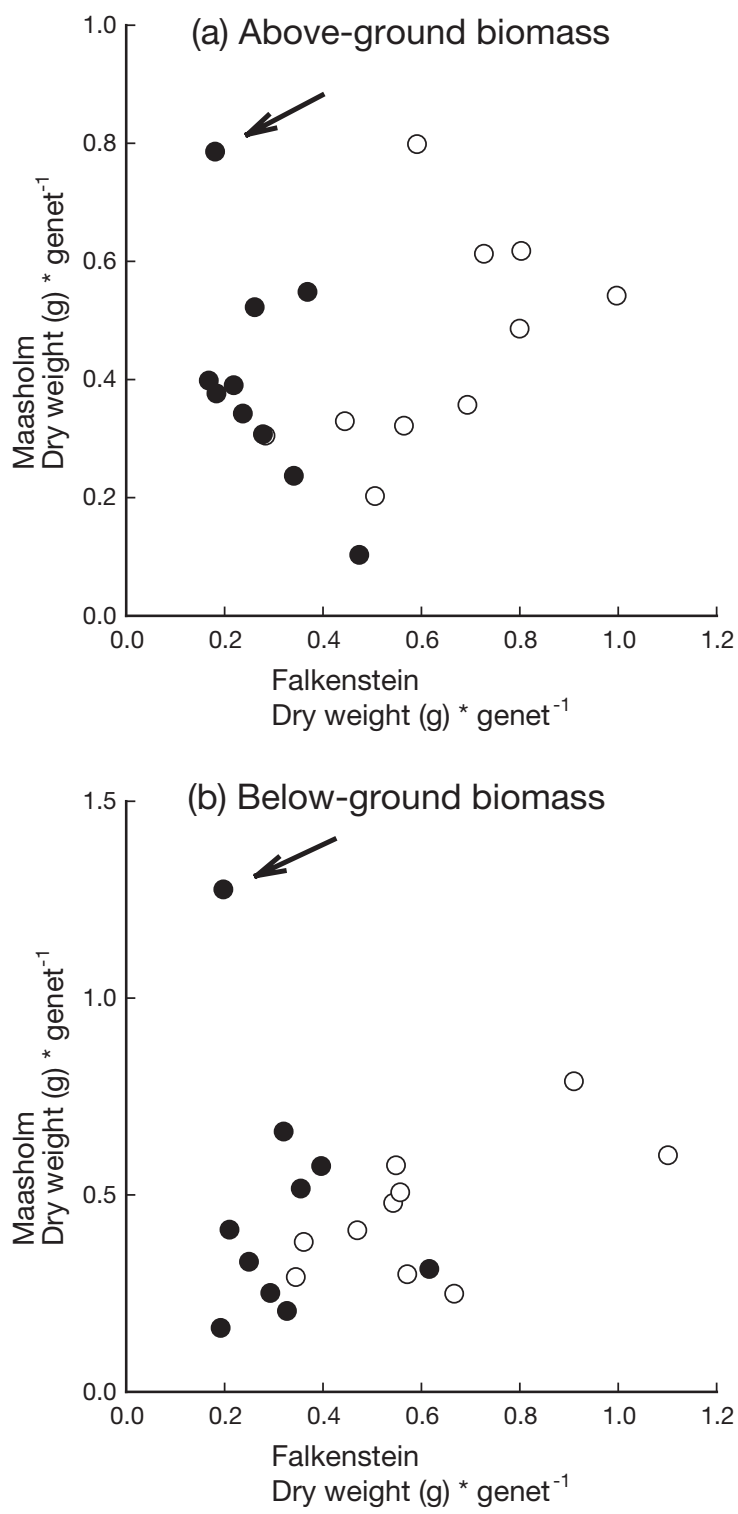

Fig. 3. Zostera marina. Range of genet performance in the 2 sites for (a) aboveground and (b) belowground biomass for clones from the 2 source sites, Falkenstein (O) and Maasholm $(\bullet)$. The values were obtained by taking the mean over all back-transplanted fragments ( $\leq 5$ rhizome fragments) of each of the 20 genets ( $x$-values for Falkenstein and $y$-values for Maasholm) and the mean over all transplanted fragments ( $\leq 5$ rhizome fragments) of each of the 20 genets ( $y$-values for Falkenstein and $x$-values for Maasholm). Arrows indicate outliers (see 'Results' for explanation)
Table 1. Zostera marina. Number of genets $\left(\mathrm{N}_{\text {genets }}\right)$, clonal diversity as $\mathrm{N}_{\text {genets }} \div \mathrm{N}_{\text {samples }}\left(\mathrm{C}_{\text {diversity }}\right)$, total number of alleles $\left(\mathrm{N}_{\text {alleles }}\right)$, mean $( \pm 1 \mathrm{SE})$ percentage of heterozygote loci (heterozygosity) and number of shoots $\mathrm{m}^{-2}$ (density), for two $15 \times$ $15 \mathrm{~m}$ plots within two $Z$. marina populations at Falkenstein and Maasholm along the Baltic Coast

\begin{tabular}{|lcc|}
\hline & Falkenstein & Maasholm \\
\hline $\mathrm{N}_{\text {genets }}$ & 104 & 121 \\
$\mathrm{C}_{\text {diversity }}$ & 0.408 & 0.567 \\
$\mathrm{~N}_{\text {alleles }}$ & 90 & 104 \\
Heterozygosity & $0.733 \pm 0.02$ & $0.717 \pm 0.018$ \\
Density $\left(\mathrm{m}^{-2}\right)$ & $347 \pm 19.91$ & $277 \pm 32.12$ \\
\hline
\end{tabular}

\section{DISCUSSION}

The significant interaction between source site and transplantation site shows local adaptation in Zostera marina for genets from Falkenstein and Maasholm. Genets from both sites showed a higher relative performance in their home population. To our knowledge, these are the first data on local adaptation of replicated genets in a seagrass species. Additionally, we found evidence for the dominance of clones from one site over the other.

At the time of harvest, genets from Falkenstein had twice as much biomass in their home population compared to transplants from Maasholm and they could keep up with the resident genotypes when transplanted to Maasholm. Since planted fragments had similar starting conditions, this indicates that Falkenstein genets were generally more efficient in occupying space than genets from Maasholm. The reasons for such transplant dominance must remain speculative. Genotypic diversity was considerably higher in Maasholm, 39\% for the plots chosen for the experiment (Table 1), which was contrary to the results of Reusch (2001), who in 1997 found a higher clonal diversity in Falkenstein based on a smaller random sample $(25+46$ genets, respectively), at slightly different locations. This does not however, change the finding that the 2 populations are part of a network of populations that seem to be highly connected (Reusch 2001). In a common garden transplant experiment, Procaccini \& Piazzi (2001) found that plants from the population with the highest genotypic diversity $(0.48$, from their Table 3) and the highest level of heterozygotes were those with the highest overall rhizome growth and branching rate. In the present experiment, the genets that could grow to a larger size during the season came from Falkenstein, the population with the lower genotypic diversity and a level of heterozygosity not significantly different from Maasholm (Table 1). 
We also found a high degree of variability in the relative performance of genets in both foreign environments (Fig. 3). Fig. 3 also shows the divergence between the groups of genets from the 2 source environments as expected from locally adapted populations (Via \& Lande 1985, Via 1994) and variability among genets from the same source population. Furthermore, genets with a high biomass yield in one site also achieved high biomass yields in the other site. These correlations were, however, only significant for the response variable rhizome dry weight (Fig. 3b).

The fragments were transplanted into a closed leaf canopy in order to simulate the environment they presumably were adapted to as closely as possible. However, it was unavoidable that the planting spots had softer sediment and the rhizomes of the transplants were less entangled compared to plants in the pristine meadow. Possibly, this slight reduction in local density decreased local competitive interactions. Several studies have shown that low density in the neighborhood can shift allocation from shoot to rhizome growth (Landhausser et al. 1996, Hubersannwald 1998, Van Kleunen et al. 2001). We suggest that similar processes explain differences between untouched controls and the back-transplants from both populations. Rhizome dry weight of back-transplants were consistently and significantly lower compared to the values from untouched controls (Fig. 2b), suggesting that transplants experienced lower competition for belowground space. Further support for this explanation comes from the sole genet from Maasholm growing in a vegetation gap at the time of harvest. It showed considerably higher values compared to the other genets from that population (outliers in Fig. 3). Population differentiation might at least in part be due to different competitive regimes (Gurevitch 1986, Wilson \& Keddy 1986). The observed differences in rhizome biomass between untouched controls and back-transplants in the present study could indicate that for Zostera marina, intraspecific interactions play an important role in local adaptation. Probably, the genetic neighborhood in a meadow rather than abiotic components constitute the environmental patchiness for $Z$. marina clones.

The present study is a first step towards understanding local adaptation in seagrasses. Some limitations of this study have to be considered carefully. Ideally, any detection of local adaptation should be based on home-site advantages measured by lifetime fitness. Such a goal is rarely feasible for long-lived clonally growing species such as Zostera marina (Kindell et al. 1996). In Z. marina, rhizome connections break over time (1 to 2 yr) leaving behind clusters of physiologically independent units that are all part of the same clone covering many $\mathrm{m}^{2}$. However, future life-history stages not examined here would have to show a reversal of the differential performance found in the present study to cancel out local adaptation. This seems unlikely considering that we transplanted independent modules of well established genets. Including future stages (e.g. larger units) would probably affect the magnitude of the observed local adaptation rather than its existence.

Early life history stages such as seedling recruitment, although presumably rare in closed meadows (Robertson \& Mann 1984, Olesen \& Sand-Jensen 1994a,b), are an important but still poorly understood component of Zostera marina population dynamics. Ruckelshaus (1994) reports on an experiment that indicated local adaptation of seeds between different tide zones based on germination rates and seedling mortality. However, experiments on early stages are susceptible to possible confounding maternal effects. For a more complete picture, it will be necessary to follow early recruitment stages over a longer time period comparing establishment in open sites with establishment in the closed meadow in the context of local adaptation.

We were mainly interested in between site effects of local adaptation using replicated genets. In a conservation context, this is the most relevant scale, as plants are often translocated over several $\mathrm{km}$ from a donor to a target site. However, it would be interesting for future experiments to look more closely at the scale to which Zostera marina clones are adapted to, e.g. to compare the close neighbourhood ( 1 to $5 \mathrm{~m}$ ) with the population scale (6 to $1000 \mathrm{~m}$ ) with a design that differentiates between transplantation back to the original site and back to the home environment, as suggested by Underwood (1990) and Chapman (2000).

Marker diversity is often used to decide which populations are most suitable as a source for translocation and restoration (Templeton 1986, Haig 1998, Knapp \& Rice 1998). The underlying assumption is that populations possessing more genetic variation also have a higher adaptive potential (Vrijenhoek 1994, Moritz et al. 1995). However, it has been argued that such a practice is not without risks (McKay et al. 2001) because plants from locally adapted populations that do not show marker diversity could still suffer from reduced fitness in a foreign environment. The 2 populations Falkenstein and Maasholm have similar genetic diversity and their genetic differentiation is small (Bohonak 1999) in absolute terms $\left(F_{\text {st }}\right.$ estimate $\theta=0.03$ ) (Reusch 2002). Only after transplantation, can we find different relative performance of genets from the 2 source sites. Therefore, it is important to support genetic data with studies on the variation of quantitative characters between populations. The results of the present study should contribute to this discussion. 
Acknowledgements. We would like to thank Anneli Ehlers and Sascha Romatzki for help in the field, Silke Carstensen and Catha Schmuck for assistance with the genetic analysis, Annelis Lüscher and 4 anonymous reviewers for comments on an earlier draft of this manuscript. This work has been funded by a grant to T.B.H.R. from the Deutsche Forschungsgemeinschaft (DFG), grant No. Re 1108/3-1 and $3-2$.

\section{LITERATURE CITED}

Andel JV (1998) Intraspecific variablity in the context of ecological restoration projects. Perspect Plant Ecol Evol Syst $1: 221-237$

Antonovics J (1971) The effects of a heterogeneous environment on the genetics of natural populations. Am Sci 59: 593-599

Antonovics J, Bradshaw AD, Turner RG (1971) Heavy metal tolerance in plants. Adv Ecol Res 7:1-85

Biosystems Applied (1998) Genotyper. PE Biosystems, Foster City, CA

Bohonak AJ (1999) Dispersal, gene flow, and population structure. Q Rev Biol 74:21-45

Callaghan TV, Carlsson BA, Jonsdottir IS, Svensson BM, Jonasson S (1992) Clonal plants and environmental change: introduction to the proceedings and summary. Oikos 63: 341-347

Chapman MG (2000) Poor design of behavioural experiments gets poor results: examples from intertidal habitats. J Exp Mar Biol Ecol 250:77-95

Costanza R, d'Árge R, Groot RD, Farber S and 9 others (1997) The value of the world's ecosystem services and natural capital. Nature 387:253-260

Den Hartog C (1970) The seagrasses of the world. Verh K Ned Akad Wet Afd Natuurkd Tweede Reeks 59:1-275

Dennison WC, Alberte RS (1986) Photoadaptation and growth of Zostera marina eelgrass translplants along a depth gradient. J Exp Mar Biol Ecol 98:265-282

Fonseca MS, Kenworthy WJ, Thayer GW (1998) Guidelines for the conservation and restoration of seagrasses in the United States and adjacent waters. NOAA'S coastal ocean program. Decision Analysis Series, No. 12, Silver Spring, MD (available at: http://shrimp.ccfhrb.noaa.gov/lab/ fonseca/guide/cover.pdf

Futuyma DJ (1986) Evolutionary biology, Vol 1. Sinauer, Sunderland, MA

Giesen WBJT, Van Katwijk MM, Den Hartog C (1990) Eelgrass condition and turbidity in the Dutch Wadden Sea. Aquat Bot 37:71-85

Gurevitch J (1986) Competition and the local distribution of the grass Stipa neomexicana. Ecology 67:46-57

Haig SM (1998) Molecular contributions to conservation. Ecology 79:413-425

Hubersannwald E (1998) Effects of nutrient patches and root systems on the clonal plasticity of a rhizomatous grass. Ecology 79:2267-2280

Janzen DH (1977) What are dandelions and aphids? Am Nat 111:586-589

Kindell CE, Winn AA, Miller TE (1996) The effects of surrounding vegetation and transplant age on the detection of local adaptation in the perennial grass Aristida stricta. J Ecol 84:745-754

Knapp EE, Rice KJ (1998) Comparison of isozymes and quantitative traits for evaluating patterns of genetic variation in purple needlegrass (Nassella pulchra). Conserv Biol 12: 1031-1041
Landhausser SM, Stadt KJ, Lieffers VJ, Mcnabb DH (1996) Rhizome growth of Calamagrostis canadensis in response to soil nutrients and bulk density. Can J Plant Sci 76: $545-550$

Lynch M (1984) Destabilizing hybridization, general-purpose genotypes and geographic parthenogenesis. Q Rev Biol 59:257-290

McKay JK, Bishop JG, Lin JZ, Richards JH, Sala A, Mitchell-Olds T (2001) Local adaptation across a limatic gradient despite small effective population size in the rare sapphire rockcress. Proc R Soc Lond Ser B 268: $1715-1721$

Moritz C, Lavery S, Slade R (1995) Using allele frequency and phylogeny to define units for conservation and management. Am Fish Soc Symp 17:249-262

Olesen B, Sand-Jensen K (1994a) Patch dynamics of eelgrass Zostera marina. Mar Ecol Prog Ser 106:147-156

Olesen B, Sand-Jensen K (1994b) Demography of shallow eelgrass (Zostera marina) populations - shoot dynamics and biomass development. J Ecol 80:379-390

Orth RJ, Moore KA (1983) Chesapeake Bay: an unprecedented decline in submerged aquatic vegetation. Science 222:51-53

Payne RW (1997) GENSTAT 5, reference manual, Release 3. Oxford Science Publications, Rodhamsted

Pranovi F, Curiel D, Rismono A, Marzocchi M, Scattolin M (2000) Variations of the macrobenthic community in a seagrass transplanted area of the Lagoon of Venice. Cient Mar 64:303-310

Procaccini G, Piazzi L (2001) Genetic polymorphism and transplantation success in the Mediterranean seagrass Posidonia oceanica. Restor Ecol 9:332-338

Reusch TBH (1998) Differing effects of eelgrass Zostera marina on recruitment and growth of associated blue mussels Mytilus edulis. Mar Ecol Prog Ser 167:149-153

Reusch TBH (2002) Microsatellites reveal high population connectivity in eelgrass (Zostera marina) in two contrasting coastal areas. Limnol Oceanogr 47:78-85

Reusch TBH, Stam WT, Olsen JL (2000) A microsatellitebased estimation of clonal diversity and population subdivision in Zostera marina, a marine flowering plant. Mol Ecol 9:127-140

Robertson AI, Mann KH (1984) Disturbance by ice and lifehistory adaptations of the seagrass Zostera marina. Mar Biol 80:131-141

Ruckelshaus MH (1994) Ecological and genetic factors affecting population structure in the marine angiosperm, Zostera marina. $\mathrm{PhD}$ thesis, University of Washington, Seattle

Schmid B, Dolt C (1994) Effects of maternal and paternal environment and genotype on offspring phenotype in Solidago altissima L. Evolution 48:1525-1549

Short FT, Wyllie-Escheverria S (1996) Natural and humaninduced disturbance of seagrasses. Environ Conserv 23: $17-27$

Solana-Arellano E, Echavarria-Heras H, Flores-Uzeta O (2000) An upgraded method to relocate marked shoots of the seagrass Zostera marina. Rev Biol Trop 48:927-930

Templeton AR (1986) Coadaptation and outbreeding depression. In: Soule ME (ed) Conservation biology: the science of scarcity and diversity. Sinauer, Sunderland, MA, p 105-116

Thiede DA (1998) Maternal inheritance and its effect on adaptive evolution - a quantitative genetic analysis of maternal effects in a natural plant population. Evolution 52:998-1015

Underwood AJ (1990) Experiments in ecology and manage- 
ment their logics functions and interpretations. Aust J Ecol 15:365-390

Van Katwijk MM, Hermus DCR (2000) Effects of water dynamics on Zostera marina: transplantation experiments in the intertidal Dutch Wadden Sea. Mar Ecol Prog Ser 208:107-118

Van Katwijk MM, Schmitz GHW, Hanssen L, Denhartog C (1998) Suitability of Zostera marina populations for transplantation to the Wadden Sea as determined by a mesocosm shading experiment. Aquat Bot 60:283-305

Van Katwijk MM, Schmitz GHW, Gasseling AP, Van Avesaath PH (1999) Effects of salinity and nutrient load and their interaction on Zostera marina. Mar Ecol Prog Ser 190:155-165

Van Kleunen M, Fischer M, Schmid B (2001) Effects of intraspecific competition on size variation and reproductive allocation in a clonal plant. Oikos 94:515-524

Van Lent F, Verschuure JM (1995) Comparative study on population of Zostera marina L. (eelgrass): experimental germination and growth. J Exp Mar Biol Ecol 185: 77-91

Van Lent F, Verschuure JM, Van Veghel MLJ (1995) Comparative study on populations of Zostera marina L. (eelgrass) in situ nitrogen enrichment and light manipulation. J Exp Mar Biol Ecol 185:55-76

Editorial responsibility: Otto Kinne (Editor),

Oldendorf/Luhe, Germany
Via S (1994) Population structure and local adaptation in a clonal herbivore. In: Real LA (ed) Ecological genetics. Princeton University Press, Princeton, NJ, p 58-85

Via S, Lande R (1985) Genotype-environment interaction and the evolution of phenotypic plasticity. Evolution 39: 505-522

Vrijenhoek RC (1994) Genetic diversity and fitness in small populations. In: Loeschcke V, Tomiuk J, Jain SK (eds) Conservation genetics. Birkhäuser, Basel, p 37-53

Watson MA, Casper B (1984) Morphogenetic constraints on patterns of carbon distribution in plants. Annu Rev Ecol Syst 15:233-258

Weiner J, Martinez S, Mullerscharer H, Stoll P, Schmid B (1997) How important are environmental maternal effects in plants-a study with Centaurea maculosa. J Ecol 85: $133-142$

Williams SL (2001) Reduced genetic diversity in eelgrass transplantations affect both population growth and individual fitness. Ecol Appl 11:1472-1488

Wilson SD, Keddy PA (1986) Measuring diffuse competition along an environmental gradient: results form a shoreline plant community. Am Nat 127:862-869

Worm B, Reusch T (2000) Do nutrient availability and plant density limit seagrass colonization in the Baltic Sea? Mar Ecol Prog Ser 200:159-166

Submitted: November 11, 2001; Accepted: June 18, 2002

Proofs received from author(s): September 18, 2002 